\title{
COVID-19 AND RISK INVOLVEMENT IN THE BANKING SECTOR OF BANGLADESH: A STUDY
}

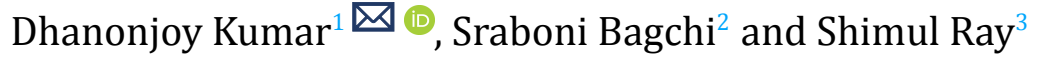 \\ ${ }^{1}$ Associate Professor, Department of Management, Islamic University, Kushtia, Bangladesh \\ ${ }^{2}$ Lecturer, Department of Tourism and Hospitality Management, Pabna University of Science and Technology, Pabna, \\ Bangladesh \\ ${ }^{3}$ Lecturer, Department of Human Resource Management, Islamic University, Kushtia, Bangladesh
}
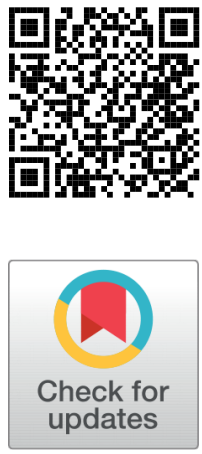

Received 9 June 2021

Accepted 21 June 2021

Published 30 June 2021

Corresponding Author

Dhanonjoy Kumar, dhanonjoykum arsaha@gmail.com

DOI $10.29121 /$

granthaalayah.v9.i6.2021.4021

Funding: This research received no specific grant from any funding agency in the public, commercial, or not-for-profit sectors.

Copyright: (C) 2021 The Author(s). This is an open access article distributed under the terms of the Creative Commons Attribution License, which permits unrestricted use, distribution, and reproduction in any medium, provided the original author and source are credited.

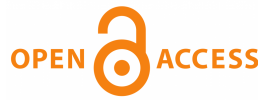

\section{ABSTRACT}

Covid-19 pandemic has arrived at a widespread risky situation in our individual, financial and communal lives. Now the whole world is thrilled by the cruel clutch of the corona virus and its victim is the global economy. The study focuses on discovering the risk involved in Covid-19 of the banking sector in Bangladesh. Qualitative approach was used to attain the purpose of this study. The study revealed that Covid-19 has a countless effect on the economy and on the banking sector in Bangladesh. In the critical moment of lockdown, Bangladeshi banking sector faces huge financial losses, increasing non-performing loans, individual investment and decreasing operating profits. Bank employees are affected seriously for performing their daily activities. They are passing their days with great fear.

Keywords: Covid19, Bank, Economy, Npls, Bangladesh

\section{INTRODUCTION}

In March 2020 Covid-19 was confirmed to have spread in Bangladesh. It was the first that there were three known cases which were testified by the epidemiology institute (IEDCR) in this country on March 8, 2020. It absolutely has spread unprecedentedly day by day and also the contagious people are increasing by leaps and bounds. So as to save lots of the masses, the government proclaimed lockdown throughout the country. Covid-19 epidemic creates financial risk within the banking sector of Bangladesh. It had been opined to the Bangladesh bank that there are fifty-nine banks in Bangladesh. These are six (06) state-owned banks, three (03) scheduled banks, nine (09) foreign commercial banks and forty-one (41) private banks. Public and private banks had 10,467 bank branches throughout the country by last November 2019. Out of total branches 5,398 were situated in urban areas and 5,069 rural 
areas Report (2020). Most of the branches of those banks are still closed during this lockdown period. Some branches were opened during this plight period with special care but transaction was limited and restricted. The banking sector of Bangladesh is already suffering miserably from non-performing loans (NPLs) and it's going to be increased for this outbreak within the near future. The NPLs will go different ways in two (02) stages, like pre-Covid NPLs and post- Covid NPLs. During this situation, the rules of Bangladesh Bank are needed for initiating and speaking to the realities. It's essential to distillate the initial bail-out policies for possible breakdown of enormous credits, which are vital for sustainability because various recessive linkages, persons and SMEs are indirectly and directly connected with large credit debtors. The banking sector faces liquidity problems for balancing deposits and faces loan recovery problems which are being declined Paul (2020).

\section{LITERATURE REVIEW}

Covid-19 has effects on shape and mind and are breaking the concept of world economy and global village. Even the globe's life science is deteriorating to curb the disease. Mahmud (2020). Banking sector is interconnected with the economy and the good strength of these sectors are not only its own strategy but also it depends on the expansion of all other sectors of the country Report (2020). Habib (2020) Bangladeshi banks are facing vast uncertainties and scepticism particularly about refunds of credits by their customers when their commercial activities are in disarray. Babu (2020) Nonperforming loans which move out from banks but don't return into their records are accused for the drop of monetary fitness. When the banks' bad loans rate will be high ultimately it decreases the strength of the banks to provide loans and increase the stockholders' risks. Murtuza (2020a) argued that the majority of the banks are in a risky position in operating profits within the half of 2020. Hasan (0200) found that almost all of the banks have made a slow growth of profits equated to the preceding year. Paul (2020) stated that the banking sector is being faced with liquidity problems and loan recovery problems. Kumar, Z; , et al. (2020) revealed that NPLs are the hot difficulties and challenges for the banking sector in Bangladesh. M. T. Hossain (2018) identified that administrative softness, lack of brilliant governance and political will are key factors for bank business being unhappy. Kumar, Z; , et al. (2020) explained that coronavirus hampers the regular activities of the agro-economy of Bangladesh. So, the value of agro-products is dropping and unsold. Finally, farmers faced huge losses. In this case generate pressure to refund the loan. Murtuza (2020a) argued that NPLs were the utmost reason for a bank's funds deficit. 


\section{OBJECTIVES OF THE STUDY}

By studying above literature and exploring the research gap, the objectives of this study could also be stated as under:

- To identify the influence of Covid-19 pandemic on the banking sector of Bangladesh.

- To identify the risk involvement in the banking sector of Bangladesh in pandemic time.

- To provide some suggestions for policy implications.

\section{RESEARCH QUESTIONS}

- What are the present economic conditions of the banking sector?

- What kinds of risks are involved in the banking sector in Covid-19 era?

- Why does the banking sector in Bangladesh face financial risk?

\section{METHODOLOGY OF THE STUDY}

This research is in descriptive nature. Its attempt is to see the varied risk involved in the banking sector of Bangladesh in post period Covid-19. Qualitative research approach has been accustomed to attain the goals of the study. For collecting data focus group method and observation method had been used. Focus group discussion was conducted on 12 bank employees of Bangladesh. Out of 12 bank employees six were state-owned bank personnel and another six were personnel of private banks. Most of them are mid-level bank employees also. The researcher personally visited four bank branches in Kushita and Jhenaidah district of Bangladesh before and after the lockdown period. The Branches are i. Agrani Bank, Islamic University Branch, Kushtia; ii. Dutch Bangla Bank, Kushtia Branch, Kushtis; iii. Sonali Bank, Sheikhpara bazar branch, Jhenaidah; and iv. Brac Bank, Jhenaidah branch, Jhenaidah. Researcher discusses with the bank employees and bank clients about banking activities, transactions, present economic status, future risk, etc. Secondary data had been collected from the published and unpublished books and journal, newspaper, periodicals, annual report of banks. The study period was 1st July, 2020 to 30th April, 2021.

\section{CONCEPTUAL FRAMEWORK OF THE STUDY}

The conceptual framework was developed on the premise of the literature review. After reviewing the literature and analyzing the research gap, some important factors need to be revealed that increase the risk of the banking sector in Covid-19 period. Figure 1 represents the important factors that increase the financial risk of the banking sector. 


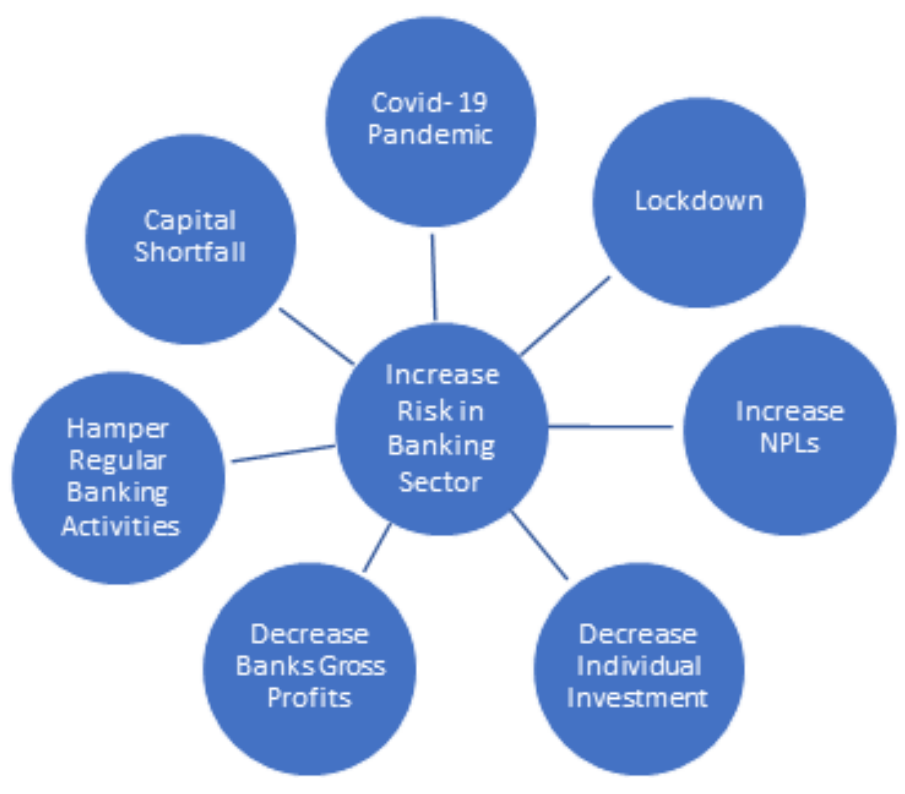

\section{ANALYSIS AND DISCUSSION}

Increased Non-Performing Loans Bangladesh: Banking sector is recently undergoing a variety of challenges like single digit charge per unit, down deposit ratio, corruption, lack of fine governance, liquidity problems, weak in depositors' confidence, low deposit rate, rumours of bankruptcy and big default loans. The largest challenge is the recovery of default loans [M. Hossain (2020) ]. According to Bangladesh Bank data at last December, the total volume of Tk. 10.18 trillion were unsettled loans. From these loans Tk. 943.31 billion were classified NPLs.

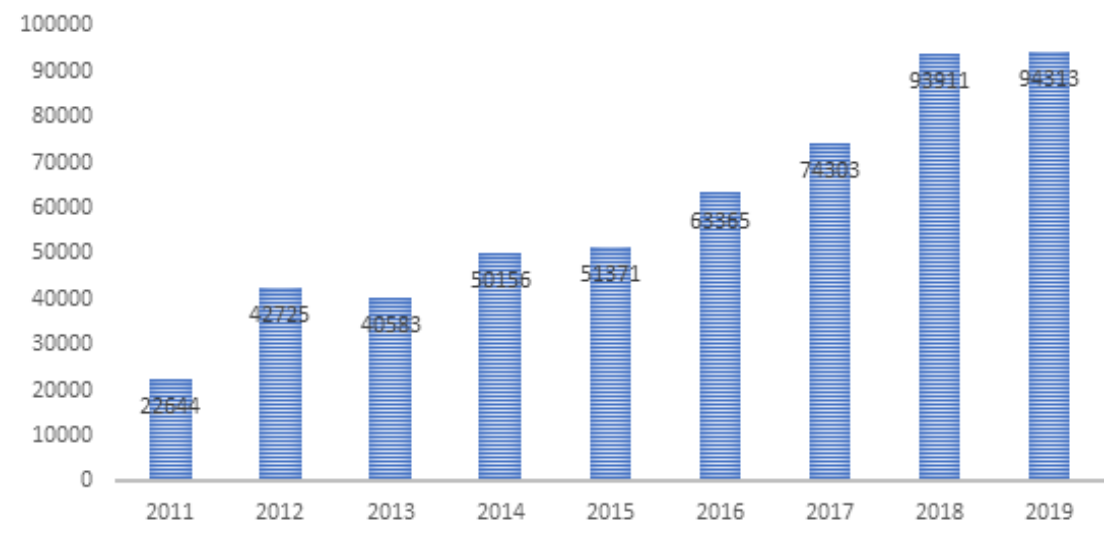

Figure 1 Represent NPLs in Taka Crore year from 2011 to 2019. Source: Bangladesh Bank Data (the daily star) 
The proportion between gross NPLs and the total unsettled credits of the bank was at $9.32 \%$ till December last 2019. This proportion has been inflamed each year from 2011 to 2019 excluding 2013. South Asia is within the top list of loan default indexes. Bangladesh's default loan ratio was projected at 11.4 percent for 2019. At highest Tk. 50,186 crore was reshuffled last year and yet failure to pay loans hit Tk. 94,313 crore at the top of 2019 and up and about 0.42 percent year on year in keeping with data from the Bangladesh Bank [Uddin (2020) ].

Decrease Operating Profit: The offensive of the awful and terrible Covid-19 epidemic is horribly upsetting the state-owned (government) commercial banks in Bangladesh. There are 11 government owned commercial banks, specialized banks and non-scheduled banks are losing a confounding Tk. 3,239 crore for interest suspension from all credits in April and continued pandemic. Banks' loss will be more because instalment payment against paid loans has been postponed till June, 2020 . For cash collections commissions, charges for rendering services of various banks have also been dropped on a shocking amount. As transactions within the securities market have been reduced to lockdown for this reason income from this sector has been reduced. The division of financial institutions under the ministry of finance has anticipated that government owned banks will face loss of Tk. 7, 717.15 crore by the covid-19 pandemic effect.

\section{Table 1 Represent the suffer of state-owned banks by Covid-19 pandemic}

\begin{tabular}{ll}
\hline Bank name & Banks's probable losses (Tk. in Crore) \\
\hline Janata Bank Limited & 2,533 \\
\hline Sonali Bank Limited & 1,600 \\
\hline Agrani Bank Limited & 1,015 \\
\hline Rupali Bank Limited & 856.9 \\
\hline Bangladesh Krishi Bank Limited & 440 \\
\hline Basic Bank Limited & 319 \\
\hline Ansar-VDP Unnayan Bank Limited & 316.25 \\
\hline Probashi Kallyan Bank Limited & 247 \\
\hline Rajshahi Krishi Unnayan Bank Limited & 179 \\
\hline Bangladesh Development Bank Limited & 150 \\
\hline Karmasangsthan Bank & 61 \\
\hline Total losses (in Tk.) & 7717.15 \\
\hline
\end{tabular}

Source: Ministry of finance, Division of financial institutions

Table 2 Represent some private banks operating profits in January to June 2020 taka in crore.

\begin{tabular}{|llll} 
Sl. No & Name & H1- 2019 & H1-2020 \\
\hline 1 & Agrani Bank Limited & 413 & 512 \\
2 & Pubali Bank Limited & 540 & 405 \\
3 & Southeast Bank Limited & 505 & 342 \\
4 & Al- Arafah Islami Bank Limited & 400 & 305 \\
\hline
\end{tabular}




\begin{tabular}{llll}
\hline \multicolumn{4}{c}{ Table 2 continued } \\
\hline 5 & EXIM Bank Limited & 330 & 317 \\
6 & NCC Bank Limited & 365 & 290 \\
7 & Shahjalal Islami Bank Limited & 325 & 247 \\
8 & Jamuna Bank Limited & 310 & 280 \\
\hline 9 & Mercantile Bank Limited & 331 & 243 \\
\hline 10 & National Bank Limited & 268 & 202 \\
11 & Social Islami Bank Limited & 295 & 175 \\
12 & Rupali Bank Limited & 75 & 130 \\
13 & Modhumoti Bank Limited & 98 & 125 \\
14 & NRB Commercial Bank Limited & 89 & 90 \\
15 & South Bangla AgricultureBank Limited & 90 & 70 \\
16 & Meghna Bank Limited & 45 & 12 \\
\hline
\end{tabular}

Source: The new age bd.

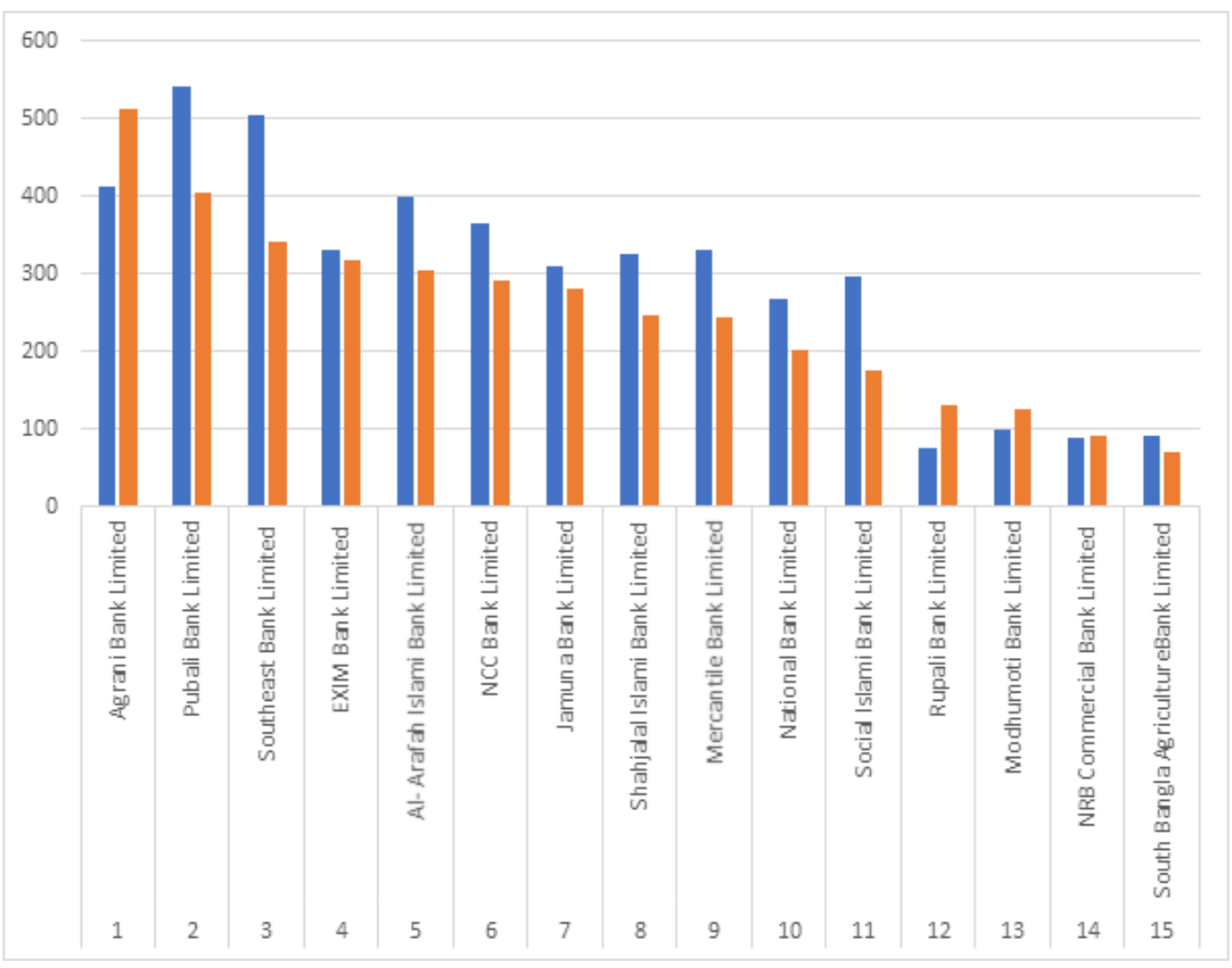

Figure 2 Comparison Operating Profits of Banks in First Half 2019 and First Half 2020 taka in crore. Source: The new age bd.

Decrease individual investment: In the period of Covid-19 pandemic, most of the people suffered plenty. They're not performing their regular activities properly. Industry, educational institutions, business organizations, financial and nonfinancial organizations are partially or fully closed during the lockdown period. After the lockdown period all organizations don't seem to be performing their work properly. 
Educational institutions are fully closed now. Industry, business, financial and nonfinancial organizations do their activities but they can't perform their activities fully fluently. Government provides the first priority to safeguard individuals from this pandemic. On the idea of the affected rate, the realm was declared a lockdown as a red zone. Within the new lockdown situation all banking et al. activities are partially or fully enclosed in that area. This is often why people's regular income was reduced and that they use their savings just for maintaining their existence. Some people stay home and keep their family safe first. Ultimate result is banks don't get proper deposits from their clients. BRAC is the largest NGO in Bangladesh conducted a survey on Covid-19 by its own income. The survey said that during the lockdown time $95 \%$ of people throughout the country suffered and lost their gross income Unb (2020).

Bank employees affected by Covid-19 and hamper regular banking activities: On Bank employees affected by Covid-19 and hamper regular banking activities. The government of the people's republic of Bangladesh proclaimed universal holidays throughout the state for coronavirus from March 26, 2020. The health affairs of the Bangladesh bank considered the bank personnel and declared insurance for them who are infected with COVID-19 for functioning at the bank. There are 2,179 bank personnel in numerous branches of banks of this state who are infected by the virus though most of them are recuperating. Out of them thirty-six (36) personnel died from the storming Covid-19 Hasan (0200). Bankers recognised that vast crowds in bank branches are the key reasons for swelling propensity of infections and deaths among bankers. But the infection and death rate increase day by day.

\section{FINDINGS OF THE STUDY}

On the idea of focus group discussion method, observation method and analysing some financial data of banks the researcher finds that Covid-19 pandemic hampers economic progress of Bangladesh seriously. Bank is the most vital steer of the economic activities of Bangladesh. During this critical moment of lockdown period payment is regarded as essential services of loan payments and instalments that were closed. For this reason, banks face a financial condition and then NPLs increase. Due to increasing the NPLs once a year the credit risk of banks increases. Recently, the govt. of Bangladesh took a choice of single digit interest about loans and every one bank has already executed it. This decision helps the borrowers but it decreases the profits of banks dramatically. Now the people of Bangladesh are stricken by Covid-19 pandemic lots. During this situation their main objectives are to be safe and sound their lives faster than others. To maintain their safety, people cannot perform their business activities hopefully so that they make a large loss. Income is that the precondition of savings and savings gives opportunity for investment. The last word result's individual's savings decreasing. Another excuse is that general people aren't so interested in saving lots of their money within the banks because the banks paid less inter- 
est than post offices or others. Mobile banking, internet banking, agent banking and ATM support help people to continue their transactions and help to manage the needful things in their life. But all banks don't provide that sort of support. Generally private banks mobile banking, internet banking, agent banking and ATM support are better than the state-owned banks. Clients enjoy mobile banking, internet banking and agent banking anywhere within the country but most of the ATM supports are located in district level branches.

\section{CONCLUSIONS OF THE STUDY}

Banks are the important financial institutions of Bangladesh. Banking risks in Bangladesh may rise by different causes. The Covid-19 epidemic is strictly touching the banking sector. The banks of Bangladesh are suffering dreadfully because of NPLs and possibly the epidemic can raise the NPLs highly. Individual investment is incredibly low at the moment. Within the period Covid-19, banking activities are happening but at a slow rate. During this situation, banks' credit risks are increasing, banks face capital shortfall, decreasing individual investment, and aren't performing their uninterrupted economic activities. Besides, bank employees are being affected regularly and death cases are occurring indiscriminately. Now it's very time for the economy of Bangladesh and for the banking sector of Bangladesh. For sustainable economic development overcoming this problem may be a must. It's time for all banks of Bangladesh to introduce mobile banking, launch internet banking, agent banking and ATM support for his or her clients. These facilities may help the bank clients to complete their valuable transactions without concern of Covid-19 pandemic. The economic support Government is the important precondition to attenuate the chance of the banking sector. The Bangladesh government takes some initiative to beat this problem. Government announces some stimulus packages for industrial sectors, banking sectors and other sectors. We expect all things are normal and also the inhabitants of Bangladesh enjoy comfortable life and economic conditions are sustainable and sustainable.

\section{RESEARCH LIMITATIONS AND FUTURE ORIENTATIONS OF THE STUDY}

This study tries to seek out some problems and supply some recommendations and it creates a replacement opportunity for investigation of the longer-term researchers. For future study, the current study is going to be further developed through collecting big data. Present situation it's very difficult to gather the massive sample size data and enormous respondents' interviews because it's time to remain home and stay safe. Last but not least, this kind of study would be interesting if the study would be extended by conducting an outsized survey, developed variables and using differing kinds of statistical tools. 


\section{REFERENCES}

ABB Starts Collecting Data On Covid-19-Affected Bankers, The Business Standard. (2020). TBS Report. Retrieved from Https://Tbsnews.Net/Coronavirus-Chronicle/Covid-19 -Bangladesh/Abb-Starts-Collecting-Data-Covid-19-Affected-Bankers-87835

Akter, R., \& Roy, J. K. (2017). The Impacts of Non-Performing Loan on Profitability: An Empirical Study on Banking Sector of Dhaka Stock Exchange. International Journal of Economics and Finance, 9(3), 126-126. Retrieved from https://dx.doi.org/10.5539/ ijef.v9n3p126 10.5539/ijef.v9n3p126

Babu, M. U. (2020). Banking Sector The Biggest Risk To Bangladesh Economy: Survey, The Business Standard. Retrieved from Https://Tbsnews.Net/Economy/Banking/Banking -Sector-Biggest-Risk-Bangladesh-Economy-Survey-45535

Habib, S. M. A. (2020). Risk Management By Banks In Post-Covid-19 Situation, The Financial Express. Retrieved from Https://Thefinancialexpress.Com.Bd/Views/Opinions/Risk

Hasan, M. (0200). Bank Staff Test Covid-19 Positive., 2. Retrieved from Https:// Www.Dhakatribune.Com/Business/Banks/2020/07/09/Around-2-200-Bank-Staff -Test-Covid-19-Positive-36-Dead.DhakaTribune

Hasan, M. (2020). First Half Of 2020: Operating Profits Of Most Commercial Banks Dip. Dhaka Tribune. Retrieved from Https://Www.Dhakatribune.Com/Business/Banks/ 2020/07/01/First

Hossain, M. (2020). Default Loans: Cancer Of The Banking System. The Financial Express. Retrieved from Https://Thefinancialexpress.Com.Bd/Views/Default-Loans-Cancer-Of -The-Banking-System-1584288344

Hossain, M. T. (2018). The Trend Of Default Loans In Bangladesh: Way Forward And Challenges. International Journal of Research In Business Studies And Management, 5(6), 24-30.

Kashem, A. (2020). State-Owned Banks Project Tk7, 717cr Losses Amid Pandemic, The Business Standard. Retrieved from Https://Tbsnews.Net/Economy/Banking/State

Kumar, D., Adhikari, P. K., \& Kumar, S. (2020). COVID-19: Its Instant Impacts Upon The Agrarian Economy Of Bangladesh. J. Bus. Econ. Manag, 8(8), 193-199.

Kumar, D., Z; Hossain, ., \& Islam, S. (2020). Non-Performing Loans In Banking Sector Of Bangladesh: An Evaluation. International Journal Of Applied Economics, 6(1), 22-29.

Mahmud, Z. U. (2020). The Impact Of Covid-19 In Banking Sector Of Bangladesh, The Daily Observer. Retrieved from Https://Www.Observerbd.Com/Details.Php?Id=255811

Murtuza, H. M. (2020a). 12 Banks Suffer Tk 17,658cr Capital Shortfall Till Sept-End, New Age Bangladesh. New Age Bangladesh. Retrieved from Https://Www.Newagebd.Net/ Article/95707/12-Banks

Murtuza, H. M. (2020b). COVID-19, Rate Cut Hit Banks' H1 Operating Profits. New Age Bangladesh. Retrieved from Https://Www.Newagebd.Net/Article/109970/Covid-19 -Rate-Cut-Hit-Banks-H1-Operating-Profits

Paul, T. C. (2020). COVID-19 And Its Impact On Bangladesh Economy, The Financial Express. Com.Bd/Views. Retrieved from Https://Thefinancialexpress.Com.Bd/Views/Covid-19 -And-Its-Impact-On-Bangladesh-Economy-1592580397

Report, F. (2020). Banks' Rural Branches Rise To 10,467, The Financial Express. Retrieved from Https://Thefinancialexpress.Com.Bd/Economy/Banks-Rural-Branches-Rise-To $-10467-1577939972$

Uddin, A. K. M. Z. (2020). Defaulted Loans Still Going Up, The Daily Star. Retrieved from Https://Www.Thedailystar.Net/Frontpage/News/Defaulted-Loans-Still-Going 
$-1869460$

Unb. (2020). Covid-19: Brac Survey Finds 95 Pc People Suffer Losses In Income. Retrieved from Http://Www.Unb.Com.Bd/Category/Bangladesh/Covid 